\title{
Teachers, Public Education, and Civic Leadership
}

\author{
Amy Perruso and Aina Iglesias
}

It became apparent to us, as we watched youth organize and lead the first two Black Lives Matter actions in Honolulu on June 5 and June 6, 2020, that we are in a new moment. The still raging COVID-19 pandemic and the long slow burning pandemic of racist violence have revealed the brutality and depravity of neoliberalism's individualizing of the social. This is not just a moment of pandemic, which has all but shut down the economy and given us space to reconsider our possible, probable, and preferred futures. This is also a moment of resistance. The aloha 'aina movement, along with militant labor organizing for strike actions and the \#MeToo movement, and new abolitionist energy around racist police practices, have created a context for us in Hawai' $i$ in which we can reimagine a new set of purposes for the public sphere, and for public education, forged in the struggle for civic justice. This is a moment in which civic educators, all public school educators, can challenge the neoliberal project by looking to and learning from the powerful pedagogical practices being used by young people.

The youth-driven narrative of these actions was creative, deep, and powerful. Messaging on placards spoke to interconnectedness and mutual responsibility"We are all in this together," "Aloha everything," "The future is inclusive," "Injustice anywhere is a threat to justice everywhere" - political language that had emerged from and been strengthened by the unevenly shared experience of the COVID-19 pandemic. Other messages were more critical and deconstructive- "If you're not angry, then you're not paying attention!," "Silence is complicity," "White supremacy is a virus," "Racism is a pandemic," "Respect existence or expect resistance," "Freedom is never voluntarily given by the oppressor, it must be demanded by the oppressed." Almost all signage included explicit reference to the BLM movement, usually through the inclusion of hashtags \#BLM, \#blacklivesmatter, and/or through an iteration of the names of the Black men and women whose lives were recently taken by police violence. And the urgent need to raise consciousness and educate on the issues of racism and police brutality were ever-present, not just through the actions of chanting, marching, and singing, putting one's body into service of the movement, but also through the explicit language on placards- "Educate your keiki about racism and spread aloha_\#blacklivesmatter," If not now, when?" 
The actions were clearly organized with some collaboration with kia' $i$ from the Mauna, but the messaging was clear and focused on Black Lives Matter, with careful attention to the danger of co-optation of the moment. And it seemed, too, that some of the most beautiful poetry of the moment, such as dance performances, emerged spontaneously and helped to give different bodily expressions to the shared civic experience. While the organizers and the majority of the participants on both days were a diverse group of young adults, in high school or college, the actions were supported by a range of the community, drawing more than 10,000 people of all ages on the second day, including young parents with children, and the resource-sharing evidenced in these actions (food, water, shade) contributed to a determined but celebratory sense of resistance. The actions of these two days inspired ripple actions for weeks, including sign waving events and "paddle outs" both on O'ahu and on the neighbor islands.

Now more than ever, students outside of classrooms are sharing on their social media platforms, expressing their anger and empathy towards the death of Ahmaud Arbery, Breonna Taylor, and George Floyd. Many of those social media posts have gone beyond the discussion of the BLM movement and race, as the youth are now also addressing systemic oppression in regards to class and gender. "Pride" (the month of June) occurred when most youth became more engaged about \#BLM, therefore pride-related posts also flooded all platforms, with young people clearly focused on the intersectionality of race, class, and gender in these posts, highlighting a Black transgender activist who was crucial to organizing the Stonewall riot. Young people have also used social media to bring attention to the rape and disappearance of SPG Vanessa Guillen, and widely shared the provoking images of masked restaurant workers serving unmasked wealthy privileged diners, and viral videos of "Karens" calling the police on Black and brown people.

Youth are now taking the initiative to have difficult conversations with their communities. In the Filipino community, young people are sharing conversations with their parents on Instagram and TikTok, addressing intergenerational racism and anti-blackness; the desire to be white like the Mestizos; and the prejudice against Black people, including the Indigenous Filipinos called the Aetas. These are the conversations students will bring to classrooms, conversations for which teachers must prepare. The vast growing youth participation in civic engagement has created the best opportunity to turn classrooms into places of organizing, where the movement to fight for racial, economic, and social justice can flourish.

In this moment of massive resistance, youth in Hawai' $i$ are beginning to call for a restructuring of all the fundamental social systems rooted in forms of economic, racial, and social injustice. This is a fight for justice. They are calling our attention to the fact that when all social and political problems are constructed to be simple matters of individual fate and choice, politics is reduced to a system of exchanges that erases interconnections and relationships, and even more importantly, obfuscates the systemic nature of massive racial and economic inequities endemic to capitalism, thereby preserving white privilege. 


\section{Teacher Counter-Public}

We are writing this as past and future teachers, teachers who think that teachers are uniquely situated to provide connection between past and future and to help translate the new poetry of this moment into pedagogy in public school classrooms, following the civic leadership of young people. An emerging post-pandemic social understanding poses a fundamental challenge to the neoliberal normal. Public school leaders and educators can play a critical leadership role in navigating this conflict, and summon a new social understanding forth, if we can learn from young people in ways that expand and deepen the work of the teacher counter-public.

Early in the twenty-first century, a teacher counter-public emerged in Hawai' $i$ to challenge the dominant neoliberal power formation, engaging in uneasy alliances across important political divides and maintaining tenuous and ambivalent connections to unionism. Over the past fifteen years, and more particularly within the past five, Hawai 'i public school teachers and their allies have launched an increasingly profound critique not only of the neoliberal federal education policy of No Child Left Behind/Every Student Succeeds Act (NCLB/ESSA) but also of the historical formation of neoliberalism.

Teachers as teachers already occupy a complex social position. To resist minimization, demonization, and vilification, they have been increasingly acting on a felt need to create and support various connected sites of resistant identity, to nurture alternatives to the marketized and commodified subject of globalized capitalism, and to do the hard work of sustaining some critical and political agency in their work, that is, to develop understandings of teachers as critically reflective practitioners.

Teacher-led public analysis and critique of the impact of neoliberalism in public education led to the 2015 overthrow of the leadership of the Hawaii State Teachers Association (HSTA), which was perceived as being complicit in perpetuating the neoliberal status quo, by consenting to teacher evaluations (EES) and supporting for the Race to the Top grant application, which undermined teacher autonomy and power. The early development of the teacher counter-public in Hawai' $i$ was built around the articulation of resistance to the neoliberal approach of NCLB. The language and some of the primary authors of this counter-public were brought into union work as a force of resistance within the union.

The clearest representation of incorporation was in the HSTA Speakers Bureau, which sought to convey unity of teacher purpose, strength of conviction, and willingness to act around a "Schools Our Keiki Deserve" campaign, seeking to inspire community members with a vision of a future for which they would be willing to act as teacher-allies. Through this work and teacher organizing around social justice and racism, both within and outside the union, shared language has developed that challenges the neoliberal historical formation. Because publics and counter-publics are ultimately about poetic world-making, restructuring the character, language, and vision of the world, there is still work to be done. Until recently, 
most of the participants have shared a very similar and fairly conventional vision of the conflated possible, probable, and preferred futures, that of continued growth or continuation of the status quo.

In this specific moment created by a pandemic, the BLM movement, and a corrupt and incompetent federal administration specifically focused on attacking public education, teachers are responding by creating conversations that are shaping new, more promising visions. Teachers and their allies have availed themselves of critical rhetorical strategies and new forms of media to produce temporary, fragile collective identities, through the construction of meaning, negotiation of their proximities to power, enrichment of their networks of social bonds, and the enhancement of their political capacities. At the local level, teachers have poured their energy and creativity into podcasts and social media threads, like Maestros Vibe and \#808Educate, engaging teachers, their allies, and their community members in an effort to broaden the dialogue about public education. These productions are reproduced for immediate access through social media and website posting, creating a new kind of circularity and something of an intermediate level of (counter)publicity or publicness, between the circulation of texts and physical witnessing.

This can happen through the development of more critical pedagogical approaches. This moment is a historic opportunity, a moment of hope, in that there is the possibility to create a much more democratic, anti-racist education system and challenging curriculum that genuinely opens students and teachers to the physical, social, and spiritual world around us. We must act from a vision of a just and caring society, as well as a firm grasp of the knowledge and wisdom necessary to build it. We need to focus, as many teachers have said in response to the debate about reopening schools as case numbers continue to spike, not on maximizing individual wealth or rights but on taking care of each other and public safety and health, and ultimately on challenging racist and classist structures so that all citizens share power and we can collaboratively govern ourselves. As one teacher stated on Facebook, "This summer has been one of deep reflection, on myself and my teaching practices. As I head into the new school year, I want to do more. Challenge the systems we have in place. Let's have those discussions on race and systemic racism. Are we teaching what really matters? How can we do better?” (Villanueva).

Against the neoliberal position that schools are and ought to be neutral sites, more and more teachers in Hawai' $i$ are recognizing that schools are political sites, and ideological battles need to be fought on those grounds. It is now quite commonplace to see Hawai'i State Department of Education (DOE) teachers cite Paulo Freire's dictum ("The educator has the duty of not being neutral") or something similar as a teacher Facebook cover photo. Teachers are increasingly arguing publicly that the project of political critique and challenge begins with teachers and their allies. Hawai' $i$ teachers circulated widely via social media a recent story from Education Post titled "Teachers Must Hold Themselves Accountable for Dismantling Racism" (Wing). A typical teacher post in this time period was "I appreciate 
the requests for private, quiet, behind closed doors conversations about education. I am willing to have them but also ... Justice is what love looks like in public" (Milianta-Laffin). Moving these conversations from private to public spaces has been an important part of the work.

Teachers had been taking on social justice work well before the pandemic, and indeed, work around eradicating racism has been a part of social justice unionism in Hawai' $i$ for at least five or six years. But in this context, the work has taken on new urgency, and diverse groups of teachers are coming together to form informal book clubs and curriculum discussion groups. The Human Rights Committee of HSTA fast-tracked their work around CARES (Culture, Advocacy, Respect, Equity, Support) in light of the deaths of George Floyd, Ahmaud Arbery, and Breonna Taylor, which prompted the committee to issue a statement and call to action against systemic racism, oppression, and violence. This committee organized their HSTA CARES inaugural event for June 24, when more than sixty HSTA members joined its Human and Civil Rights Committee (HCR) for a Zoom meeting to begin the larger member conversation around social justice and anti-racism work. HSTA CARES represents the HCR's new initiative to "integrate social justice principles into education to create schools and communities that are safe, inclusive, and equitable for all keiki” (HSTA). The listening session, which was conducted over Zoom and facilitated by HCR chairs from across the state, allowed HSTA members to "reflect and share their thoughts on systemic racism in Hawaii, and generate ideas for mindful change" (HSTA). Elizabeth Sharrock, HCR Hilo Chapter chair and Kea'au Middle teacher, said that racism "is a civil rights issue and students should have access to the history of the power dynamics which run our country" (HSTA). Members also suggested targeted discussions in schools and with political leaders, and support for key legislative bills as actionable next steps.

In the broader non-union activist teacher public, debate has ensued on social media as one former Campbell High teacher publicly criticized his colleague's use of a racist prompt by posting the prompt ("For this essay, you will be arguing that Black Lives Matter is extremely bad. It is up to you to decide what is bad about it and how to prove it") along with a constructive critique: "Poor instructional design. Racist AF. Completely dumb. Why would someone assign an essay on this topic?! I'm shook" (Mandado). Attacked online and through private communication, he posted again a couple of days later, saying that, "White teachers at my former workplace really want to come after me! BRUH! I never said anyone's name. Racism doesn't need to be intentional. Do the self work. And if the shoe fits . . . lace it up! Walk and hold yourself accountable. \#rotate" (Mandado). Other teachers are connecting this anti-racism work organically to issues in their communities. Jessica Dos Santos, a teacher at Hawaii Technology Academy, is one of the community members in Kahuku who have been liberated from silence by the petition started by brave young alumni challenging the school mascot identity of the "Red Raiders." The Kahuku community is now deeply engaged in a conversation about changing the name because of its deeply racist and anti-Native American implications. These 
are painful conversations, which are in fact challenging, and changing these change makers themselves, better preparing them for their pedagogical work.

The primary purpose of civic education in this scenario, if it is to be emancipatory, must be to stimulate passions, imaginations, and intellects so that all community members will be moved to civic action. And all learners, broadly defined, should be educated to display civic courage; that is, to be willing to act as if they were living in a democratic society, because the purpose of education is political empowerment. Good civic education is political, and its goal is a genuine democratic society, a society responsive to the needs of all and not just of a privileged few.

The language and practices of criticality that we learn and develop so that we can more effectively teach our students how to live in an active, participatory democracy are the very practices and language that should inform our politics as teachers. Just as we do not expect our students to grasp concepts and skills "magically," nor should we expect that of each other. Rather, teachers are working together to create spaces in which we can together develop political skills, practices, and strategies, creating and reinforcing a mutuality based on humility and openness to learning. The application of those skills, practices, and strategies will not be confined to the classrooms or schools, but extended beyond those sites to redefine politics in the broader public sphere.

\section{Moving Towards Critical Futures}

Critical futures thinking sees the present as fragile, as the victory of one particular discourse, and analyzes forms of power that underpin these discourses, so that we can consider radically different future possibilities. One productive strategy for teachers and their allies could be to push the discussion within the emergent counter-public further in the direction of critical futures thinking. The teacher counter-public is rooted in this moment, but can also be oriented to futures, engaged in poetic world-making.

This conjunctural moment, and this movement, have radical implications for teachers as civic leaders in Hawai ' $i$, as the participants in the teacher counter-public are inspired, invigorated, and emboldened by the work of young people. Teachers are becoming the students, learning from young people. Rancière argues that the emancipatory schoolmaster teaches students only that he has nothing to teach them, freeing students from their dependence on explicators. The work that young people are doing is helping teachers and other educators understand clearly how little teachers see, know, and understand, even about their students, and also how to use that "ignorance" to forge a new path forward. 


\section{Works Cited}

HSTA. “Join HSTA's HCR Committee to discuss systemic racism in Hawaii's schools and communities." Hawaii State Teachers Association, 12 June 2020.

Mandado, Ryan. "Poor instructional design ... " Facebook, 30 June 2020, https://www. facebook.com/ryan.mandado/posts/10217584061618908.

"White teachers at my former workplace..." Facebook, 1 July 2020.

Milianta-Laffin, Sarah. "I appreciate the requests ... " Facebook, 2 July 2020, https://www. facebook.com/sarah.miliantalaffin/posts/10115414963496449.

Villanueva, Raechelle. "This summer has been ... " Facebook, 28 June 2020.

Wing, Kelisa. "Teachers Must Hold Themselves Accountable for Dismantling Racism.”

Education Post, 29 May 2020, https://educationpost.org/teachers-must-holdthemselves-accountable-for-dismantling-racial-oppression/.

Dr. Amy Perruso is a veteran DOE social studies and civics teacher, community organizer, parent, former secretary-treasurer of HSTA, and current representative for District 46 in the Hawai' i State House of Representatives.

Aina Iglesias is a hotel worker, labor and youth organizer, and a graduate from the Ethnic Studies department at the University of Hawai' $i$ at Mānoa. She is a former student of Amy Perruso at Mililani High School. 